\title{
ASSESSED TAXATION IN THE HEALTH CARE SECTOR IN UKRAINE AND FOREIGN COUNTRIES: COMPARATIVE AND LEGAL ANALYSIS
}

DOI: 10.36740/WLek202002132

\author{
Vladislav I. Teremetskyi' ${ }^{1}$ Oleksandr M. Bandurka² , Emiliia S. Dmytrenko ${ }^{3}$, Natalia I. Atamanchuk ${ }^{4}$, \\ Oleksandra 0. Kochura ${ }^{2}$ \\ ${ }^{1}$ TERNOPIL NATIONAL ECONOMIC UNIVERSITY, TERNOPIL, UKRAINE \\ ${ }^{2}$ KHARKIV NATIONAL UNIVERSITY OF INTERNAL AFFAIRS, KHARKIV, UKRAINE \\ ${ }^{3}$ KYIV NATIONAL ECONOMIC UNIVERSITY NAMED AFTER VADYM HETMAN, KYIV, UKRAINE \\ ${ }^{4}$ UNIVERSITY OF THE STATE FISCAL SERVICE OF UKRAINE, IRPIN, UKRAINE
}

\begin{abstract}
The authors have defined and revealed the mechanism for collecting personal income tax, value added tax, single tax relating to health care sector in Ukraine and their analogues in other countries. Special attention has been paid to the problems in this field in Ukraine and the ways of their solution have been suggested. It has been proved that the mechanism of legal regulation of assessed taxation in the health care sector in Ukraine needs to be improved. Taking into account international experience, the authors have offered to amend the Tax Code of Ukraine on: the use of tax incentives of state support (USA); progressive assessed taxation of individual income (Spain, Germany, Poland, Slovakia, etc.); value added tax rates and benefits (USA, France, Hungary) and so on.
\end{abstract}

KEY WORDS: health care, assessed taxation of medical supply operations, value added tax, tax benefits

Wiad Lek. 2020;73(2):374-379

\section{INTRODUCTION}

An important element in the functioning of any state is the health care system. Its purpose is to provide affordable health care services to citizens. The Article 49 of the Constitution of Ukraine enshrines the right of everyone to health care. This right is realized through the provision of free medical care in state and municipal health care institutions (medical institutions) and through the development of medical institutions of all forms of ownership by the assistance of the state. Ukraine seeks to move closer to international health standards and, to that end, the state accomplishes its reforming, aimed at providing citizens with quality and affordable health care services (medical services).

Assessed taxation is one of the means of regulating health care sector. The main taxes paid by medical institutions in conducting operations on the supply of medical services are the personal income tax, value added tax, single tax. However, the mechanism of legal regulation of assessed taxation in the health care sector in Ukraine is currently imperfect. That is why it is important to analyze the peculiarities of legal regulation of this issue and to find its effective model, including the experience of foreign countries.

\section{THE AIM}

The aim of the article is to conduct comparative and legal research of assessed taxation in the health care sector in Ukraine and foreign countries, to find out the problems in this field in Ukraine and the ways to solve them. The main task of the article is to determine and reveal the peculiarities of the payment of certain taxes by medical institutions, to identify the shortcomings of the assessed taxation mechanism in the analyzed area, and to suggest the ways to improve the legislation of Ukraine in this area, including the experience of foreign countries.

\section{MATERIALS AND METHODS}

In order to obtain the results on the peculiarities of assessed taxation in the health care sector, the authors have carried out the analysis of the norms of tax legislation of Ukraine and other countries, documents of the State Fiscal Service of Ukraine (since September 2019 - the State Tax Service of Ukraine), the Ministry of Health of Ukraine. The authors have analyzed the statistics on the mechanisms of financing the health care system in the Member States of the Organization for Economic Co-operation and Development, on the amount of tax-financed expenditures within the total health care costs in the USA, as well as on the tax rates in some countries of the European Union. In order to determine the shortcomings of legal regulation in this area, the authors have carried out the results of the National Online Surveys and Social Surveys "LEAGUE: Law" conducted in Ukraine in 2019, as well as the Report of the Accounting Chamber on the results of the audit of the effectiveness and validity of the application of value added tax benefits 
Table 1. Tax-Financed Health Care Expenditures (billions of dollars): United States, 2013-2024 [3, p.450].

\begin{tabular}{|c|c|c|c|c|c|}
\hline Expenditures & 2013 & 2014 & 2015 & 2020 & 2024 \\
\hline Total national health care expenditures & 2919 & 3080 & 3244 & 4274 & 5425 \\
\hline Total tax-financed expenditures & 1877,4 & 1999,4 & 2108,8 & 2807,8 & 3642,1 \\
\hline $\begin{array}{l}\text { Tax-financed expenditures, in percentage of total national health } \\
\text { care expenditures, } \%\end{array}$ & 64,3 & 64,9 & 65,0 & 65,7 & 67,1 \\
\hline
\end{tabular}

Table 2. Mechanisms for Financing the Health Care System in Eight OECD Countries [5, p.8].

\begin{tabular}{cr}
\hline Country & Health care system's financing (payer) \\
\hline Australia & Public (general taxation+health care tax) \\
\hline Canada & Public (general taxation) \\
\hline France & Social medical insurance (statutory) and public (general+health care tax) \\
\hline Germany & Social health insurance (statutory) and public (general taxation) \\
\hline Italy & Mixed (social medical insurance and public one) \\
\hline Poland & Public (health care tax+general taxation) \\
\hline Spain & Public (general taxation+national insurance) \\
\hline United Kingdom & Public (general taxation) \\
\hline
\end{tabular}

for operations on providing health care services. Methods of analysis, synthesis, generalization, systematization have been used during the research.

\section{REVIEW AND DISCUSSION}

Health care sector is nowadays actively reformed in all countries, since systems that use data in order to continue to exist as usual and to politically preserve and seek to realize new economic and medical resources [1]. For example, the US health care field must work to ensure that all individuals have access to affordable and equitable health services $[2,1271]$. To this end, the proportion of tax-financed expenditures within total health care expenditures is increased annually in the United States (Table 1) ${ }^{1}$ :

Tax revenues are the main source of government funds available for financing and expanding $[4,182]$, including the health care sector. Such financing mechanism is used, in particular, in the countries of the Organisation for Economic Co-operation and Development, along with the social medical insurance and mixed financing (Table 2$)^{2}$.

An important issue for further development of all countries under current conditions is the balancing the costs for health care sector. Thus, one of the areas in which the Polish health care system should develop is the commercialization of health care facilities - public hospitals and medical centers $[6,49]$. Another direction is to improve assessed taxation of this area in general and in particular, the mechanism of granting tax benefits taking into account the experience of other countries. For example, nonprofit hospitals under US law are exempt from federal, state, and local taxes $[7,545]$.

The positive factor of medical reform in Ukraine, which is carried out through the prism of current world tendencies in this field, is the reorganization of medical institutions from budgetary institutions into municipal non-profit enterprises with the status of non-profit organizations. Another area of medical reform is to improve the operations' taxation mechanism for medical supply and other activities carried out by medical institutions.

The general mechanism of taxation in the health care sector is defined by the provisions of the Tax Code of Ukraine. Besides, the norms of by-laws affect the procedure of their charging. In particular, the Guidelines on the transformation of health care institutions from budgetary institutions into municipal non-profit enterprises, prepared by the Ministry of Health of Ukraine, state that these enterprises do not pay: corporate income tax (if they do not violate the conditions of non-profit status); real estate tax other than land plot; land tax (if fully funded by the budget); single tax. However, they pay value added tax in accordance with the requirements of the Tax Code of Ukraine [8;9].

As for the payment of the single tax, in accordance with Articles 291-293 of the Tax Code of Ukraine, its payers may be medical employees-individual entrepreneurs, who provide medical services. Usually, they are taxpayers of the second group and pay a flat single tax (within 20\% of the minimum wage). However, if they receive payment for medical services from insurance companies that are legal entities (fully or partially) or provide paid medical services 
Table 3. Costs for Tax Subsidies for Private Employers is Medical Insurance (billions of dollars): United States, 2013-2024 [3, p.450].

\begin{tabular}{cccccc}
\hline Expenditures & $\mathbf{2 0 1 3}$ & $\mathbf{2 0 1 4}$ & $\mathbf{2 0 1 5}$ & $\mathbf{2 0 2 0}$ & $\mathbf{2 0 2 4}$ \\
\hline Tax subsidies for private employers - medical insurance & 249,2 & 262,7 & 276,4 & 345,9 & 453,2 \\
\hline
\end{tabular}

Table 4. Progressive Scale of Individuals Income Taxation in the EU Countries [13].

\begin{tabular}{cc}
\hline Country & Tax rate \\
\hline France & 5-graded: from 14 (for certain payments - from 0) till 45\% \\
\hline Germany & 5- graded: from 14 (for certain payments - from 0) till 45\% \\
\hline Spain & 5- graded: from 9,5 till $22,5 \%$ \\
\hline Poland & 2- graded: 18 and $32 \%$ \\
\hline Slovakia & 2- graded: 19 and $25 \%$ \\
\hline
\end{tabular}

for legal entities in accordance with the concluded contracts, then they must register as the third group single tax payers in the amount of $3 \%$ of income (in case of payment of value added tax) or 5\% of income (in case of inclusion of value added tax in the single tax). These taxpayers may realize the right to apply a simplified taxation system in the next calendar year, in case their income during the calendar year does not exceed: for taxpayers of the second group, UAH 1,500,000; of the third group - UAH 5,000,000 [10].

Medical institutions as small and medium-sized enterprises in foreign countries do not use the simplified taxation system, since they are provided with other tax incentives of the state support. Thus, the tax on small business investment has been abolished in the US since 2010. However, the Law "On Tax Burden Relief and Creating New Jobs" allows the use of accelerated depreciation method for equipment purchased by small companies after September 8, 2010. Small companies with a turnover of less than $\$ 50$ million can also use all types of credit to reduce the amount of the alternative minimum tax $[11,153]$. We believe that this can be taken into account in the formation of an optimal health tax policy.

The specific feature of a medical institution as a taxpayer is the fact that it also acts as a tax agent for paying personal income tax by medical employyes, who work in such an institution under an employment contract. Herewith, the latter (as any taxpayers) can realize the right to a tax rebate, if they demonstrate expenses actually incurred during the tax year in the annual Wage and Tax Statement evidenced by the documents. In particular, a taxpayer or a first-degree family member has the right in accordance with the Art. 166 of the Tax Code of Ukraine, to include the amount of money to the tax rebate paid by him in favor of medical institutions - as the compensation for the cost of paid treatment services.

Besides, a tax rebate is also provided for the amount of money paid by the taxpayer recognized as a disabled person or his or her disabled child in favor of prosthetic and orthopedic enterprises, rehabilitation institutions to compensate the cost of the respective paid services [10].
Analyzing the US experience of paying personal income tax, the taxation procedure is somewhat similar to that existing in Ukraine. Thus, the taxable income of a federal individual income tax is determined by the subtraction of tax rebates and benefits from adjusted gross income. However, this tax system in the US is progressive - taxpayer's taxable income is divided into tax categories. And the mechanism of tax rebates depends on the category of payers (filing status): single; married payer filing the declaration separately from the husband (wife); married payer filing the declaration together with the husband (wife); head of household; widowed person with the dependent child [12]. Besides, federal, state and local tax subsidies for health care and health insurance tax subsidies are provided to private employers [3, 449]. The amounts of expenditures for these purposes are contained in Table $3^{3}$.

We believe that some of these provisions are worth considering while improving the taxation of personal income in Ukraine, including the progressive scale of taxation of their income. It is also appropriate to study the experience of certain EU countries, where there are several levels of personal income taxation (Table 4$)^{4}$.

Particularly, we would like to emphasize the peculiarities of paying the value added tax by medical establishments in Ukraine, since operations for the provision of services under the Art. 185 of the Tax Code of Ukraine are the object to this tax [10]. The basis for the mandatory registration of the provider of medical goods (services) as the taxpayer is the total volume of operations for their supply (must exceed UAH 1,000,000 in the last 12 months) [14]. The State Fiscal Service of Ukraine, in its letter dated from September 12, 2016, No. 19610/6 / 99-99-15-03-02-15, explained that the total volume of such transactions include transactions subject to taxation at the basic rate of $7 \%$, zero rate and value added tax exempt. The Supreme Court of Ukraine has the same position, when considering disputes on similar legal relations [15].

Typically, the value added tax rate is set at $20 \%$ of the tax base. However, operations for the supply on the customs ter-

\footnotetext{
${ }^{3}$ Indicators taken from Himmelstein DU, Woolhandler S. The Current and Projected Taxpayer Shares of US Health Costs. Am J Public Health. 2016. 106(3). Pp. 450.

${ }^{4}$ Source: Podatky v Ukraini vs krainy YeS: de platiat bilshe? Aviable from: http://cost.ua/news/714-podatky-v-ukrayini-vs-krayiny-eu-de-platyat-bilshe; European Commission
} 
Table 5. Average Characteristics Scores (on-scale from 1 till 6) [20].

\begin{tabular}{ccc} 
E-services & Legal entities & Individual entrepreneurs \\
\hline $\begin{array}{c}\text { The work of the service. Accession to the agreement on recognition } \\
\text { of electronic documents }\end{array}$ & 4,29 & 4,42 \\
\hline The work of the service of "E-Cabinet" & 4,23 & 4,17 \\
\hline The work of the Publicly availible information and reference resource & 4,05 & 4,19 \\
\hline
\end{tabular}

ritory of Ukraine and the importation of medicinal products into the customs territory of Ukraine under the conditions specified in the Art. 193 of the Tax Code of Ukraine (must be: authorized for production and use in Ukraine, entered in the relevant registers or meet the requirements of the relevant technical regulations) at the rate of $7 \%$. In regard to medicinal products, medical devices and medical equipment authorized for use in clinical trials, the condition of application of the $7 \%$ rate is the availability of the permit from the Ministry of Health of Ukraine to conduct trials [10].

The List of medicinal products and means, operations on the supply on the customs territory of Ukraine and importation into the customs territory of Ukraine, which are subject to value added tax at the rate of 7\%, is defined by the Resolution of the Cabinet of Ministers of Ukraine dated from September 3, 2014, No. 410 [16]. Analysis of the content of the List indicates about its imperfection, since operations for the supply of other similar medicinal products and means, not provided by it, are taxed at the rate of $20 \%$. Therefore, the List is advisable to review, defining clear criteria for its formation. Another problem is that the introduction of the $7 \%$ rate on the supply of analyzed medicinal products in 2014 was one of the reasons for the increase in prices for some of them, which are higher than in the EU countries, where reduced rates on the supply operations for these goods (Hungary - 5\%, France - 5.5\%) are also applied [13]. In order to reduce the price for medicinal products, we offer to reduce the value added tax rate for operations on the supply of such products, having studied the experience of some EU countries.

The above points to the fact that benefits are important elements of the taxation mechanism of the health care sector in many countries. As previously noted, almost all non-profit hospitals in the US are exempt from federal, state, and local taxes, but like tax-exempt organizations generally, taxexempt hospitals must undertake activities that benefit their communities $[17,1225]$. We believe that this approach to the provision of tax benefits to medical institutions should be envisaged in the legislation of Ukraine.

Regarding operations for the supply of health care services by health care institutions, as well as rehabilitation institutions for persons with disabilities and children with disabilities, having the appropriate license, they shall be exempt from value added tax in accordance with the paragraph 197.1.5, paragraph 197.1.5 of the Art. 197 of the Section V of the Tax Code of Ukraine [10]. However, the content of the analyzed norm needs to be improved by restricting the categories of persons to whom medical services are provided by such institutions. The notions of "standard-care facility" and "improved service facility" also need to be defined for better definition of the List of medical services, whose supply operations are exempt from the taxation by this tax.

The issues of efficiency and reasonableness of the application of tax benefits from the value added tax on supply operations of health care services were the subject matter of an appropriate audit conducted by the Accounting Chamber (report dated from March 19, 2019, No. 6-5) during 2016 - September 2018. The audit found out that the Ministry of Health of Ukraine had carried out improper monitoring over the compliance with the requirements of the Licensed Conditions for conducting business activities on medical practice (planned activities were carried out only in the IVth quarter of 2016, violations of the law were found out in $100 \%$ of inspected institutions). Such activity also took place without proper state registration and registration in the tax authorities ( 884 business entities with licenses were found out during the analyzed period; although according to the data of the State Fiscal Service of Ukraine they went out of business until January 1,2016). The results of the said audit also indicate about improper control by the State Fiscal Service of Ukraine in the analyzed area (the volume of VAT surplus into the state budget amounted to over UAH 4.6 billion). Some medical institutions - taxpayers do not report the tax authorities about the received amount of tax benefits (about $65 \%$ of taxpayers did not report in 2015, in 2016-2017 - about 50\%), and the latter are not applied to taxpayers as penalties for such violation (in 2017 applied to only $18 \%$ of taxpayers) [18].

One of the reasons for these violations is the poor standards of supervision in the health care sector and tax control. Therefore, it is advisable to review the norms on the responsibility of the Ministry of Health of Ukraine, the State Tax Service of Ukraine for improper supervision and control in regard to its strengthening. According to the opinion of $45.6 \%$ of the respondents who took part in the survey conducted by "LIGA: Law" in $2019(1,500$ respondents took part), it is advisable to introduce the personal responsibility of the officials of the controlling agencies for unjust decisions [19].

In addition, the results of the above survey indicate that another reason for the offenses within the analyzed area is too frequent amendments to the Tax Code of Ukraine. Amendments in the legislation over the last year, respondents rated as neutral (41.4\%), negative (26.6\%), completely negative $(22.5 \%)$ and supported a ban to amend tax legislation for one year before the start of the new fiscal year [19].

${ }^{5}$ Indicators according to the National On-line Taxpayers'Survey, conducted on the web-portal of the State Fiscal Service of Ukraine in May 2019 
We also analyzed the results of the Nationwide online survey of taxpayers conducted on the web portal of the State Tax Service of Ukraine in May 2019 with the participation of 587 respondents. Attention was paid to the taxpayers' assessment concerning the use of e-services demonstrated in Table $5^{5}$.

The results of the survey indicate the need to improve the functioning of the E-Cabinet and the service of providing electronic signature service, as well as the introduction of a procedure for informing about fines [20]. The latter proposition is due to the fact that there are cases of inspections by the State Tax Service of Ukraine of improperly charging medical establishments with value added tax and penalties, as evidenced by the existing court practice to appeal the results of such inspections. A bright example may be the Decision of the Administrative Court of Appeal of Odessa dated from July 26, 2018 in case No. 815/263/18 [21].

In view of the above, it is advisable to study the US experience in regard to the Pre-Operational Monitoring Program (CAP), the main task of which is to work out concerted decisions between the tax authority and the taxpayer to reflect some transactions in the tax accounting prior to filing tax statements. This requires taxpayers to have a much higher level of transparency and trust than a regular audit of already filed tax statements, as taxpayers are obliged to provide the tax authorities with reliable information on material transactions [22].

\section{CONCLUSIONS}

Obtained results of the research of assessed taxation in the health care sector in Ukraine indicate that there are problems in this area. They are related to both imperfect legislation and inadequate control and supervision by the Ministry of Health of Ukraine and the State Tax Service of Ukraine. A number of problems in the analyzed area are caused by the problems of electronic services and resources' functioning.

Therefore, the mechanism of legal regulation of assessed taxation in the health care sector in Ukraine needs to be improved. Taking into account the experience of other countries, the main directions for introducing an optimal model of assessed taxation in this area in Ukraine can be as follows: 1) use of tax incentives of state support - on the US model;

2) introduction of progressive assessed taxation of personal income - on the model of Spain, Germany, Poland, Slovakia, etc.;

3) application of reduced rates and benefits from value added tax - on the model of the USA, France, Hungary;

4) improvement of the electronic service's functioning for taxpayers - on the US model;

5) introduction of the program of preliminary monitoring of transactions with the purpose of working out the agreed decisions between the tax authority and taxpayers with demonstration of certain transactions in the fiscal accounting even before submission of the tax reporting - on the US model.

The implementation of the above will indicate Ukraine's desire to move closer to international standards in this field in order to provide citizens with quality and affordable health care services.

\section{REFERENCES}

1. Saltman RB. Structural effects of the information revolution on taxfunded European health systems and some potential policy responses. Isr J Health Policy Res. 2019;8(1):8. doi: 10.1186/s13584-018-0284-2.

2. Bhatt, Jay, Bathija, Priya. Ensuring Access to Quality Health Care in Vulnerable Communities. Academic Medicine. 2018; 93(9):1271-1275.

3. Himmelstein DU, Woolhandler S. The Current and Projected Taxpayer Shares of US Health Costs. Am J Public Health. 2016; 106(3): 449-452.

4. Mccoy D, Chigudu S, Tillmann T. Framing the tax and health nexus: a neglected aspect of public health concern. Health Econ Policy Law. 2017;12(2):179-194. doi: 10.1017/S174413311600044X.

5. Angelis A, Tordrup D, Kanavos P. Is the funding of public national health systems sustainable over the long term? Evidence from eight OECD countries. Global Policy. 2017; 8:7-22.

6. Jaworzynska M. A Comparative Analysis of the Health System Financing in Poland and Selected Countries. Economics and Sociology. 2016; 9(3):41-51 doi: 10.14254/2071-789X.2016/9-3/4.

7. Daniel B. Rubin, Simone R. Singh, Gary J. Young. Tax-Exempt Hospitals and Community Benefit: New Directions in Policy and Practice. Annu. Rev. Public Health 2015; 36: 545-557.

8. Metodychni rekomendatsii Ministerstva okhorony zdorovia z pytan peretvorennia zakladiv okhorony zdorovia z biudzhetnykh ustanov u komunalni nekomertsiini pidpryiemstva onovlena versiia. 2018: 40-44. Aviable from: https://moz.gov.ua/uploads/0/3562-moz_metod_ recomendations_autonomization_2018_ua_final_web.pdf.(InUkrainian).

9. Onyshchenko V. Opodatkuvannia u medzakladakh pislia peretvorennia u komunalni nekomertsiini pidpryiemstva. Aviable from: https://www. golovbukh.ua/article/7432-opodatkuvannya-u-medzakladah-pslyaperetvorennya-u-komunaln-nekomertsyn-pdprimstva. (In Ukrainian).

10. Podatkovyi kodeks Ukrainy vid 02.12. 2010 roku № 2755-VI. Aviable from: https://zakon.rada.gov.ua/laws/show/2755-17. (In Ukrainian).

11. Holoborodko T.V. Oblik ta opodatkuvannia subiektiv maloho biznesu z zarubizhnykh krainakh v umovakh zastosuvannia mizhnarodnykh standartiv finansovoi zvitnosti. Prychornomorski ekonomichni studii. 2016; 12 (2):149-154. (In Ukrainian).

12. Hrechana V. Zahalni zasady opodatkuvannia v SShA indyvidualnym prybutkovym podatkom. Yurydychna Hazeta. 2016;44(542). Aviable from: http://yur-gazeta.com/publications/practice/podatkovapraktika/podatki-na-amerikanskiy-lad.html. (In Ukrainian).

13. Podatky v Ukraini vs krainy YeS: de platiat bilshe? Aviable from: http:// cost.ua/news/714-podatky-v-ukrayini-vs-krayiny-eu-de-platyatbilshe. (In Ukrainian).

14. Brahinskyi P. Pro neobkhidnist reiestratsii platnykom PDV nadavachiv medychnykh posluh. Aviable from: https://healthreform.in.ua/3969-2/. (In Ukrainian).

15. LystDerzhavnoi fiskalnoi sluzhby Ukrainy vid 12.09 .2016 № 19610/6/9999-15-03-02-15. Aviable from: http://sfs.gov.ua/baneryi/podatkovikonsultatsii/konsultatsii-dlya-yuridichnih-osib/69858.html. (In Ukrainian).

16. Pro zatverdzhennia Pereliku medychnykh vyrobiv, operatsii z postachannia na mytnii terytorii Ukrainy ta vvezennia na mytnu terytoriiu Ukrainy yakykh pidliahaiut obkladenniu podatkom na dodanu vartist za stavkoiu 7 vidsotkiv: Postanova Kabinetu Ministriv Ukrainy vid 03.09.2014 №410. Aviable from: https://zakon.rada.gov.ua/laws/ show/410-2014-\%D0\%BF. (In Ukrainian). 
17. Sara Rosenbaum, David A. Kindig, Jie Bao, Maureen K. Byrnes, Colin 0 'Laughlin. The Value Of The Nonprofit Hospital Tax Exemption Was \$24.6 Billion In 2011. Health Affairs. 2015; 34 (7): 1225-1233. http:// doi.org/10.1377/hlthaff.2014.1424.

18. Zvit pro rezultaty audytu efektyvnosti ta obgruntovanosti zastosuvannia podatkovykh pilh z podatku na dodanu vartist za operatsiiamy z postachannia posluh z okhorony zdorovia: Zatverdzheno rishenniam Rakhunkovoi palaty vid 19.03.2019 № 6-5. Aviable from: https://rp.gov. ua/upload-files/Activity/Collegium/2019/6-5_2019/Zvit_6-5_2019. pdf. (In Ukrainian).

19. Tsyhanok Yu.V Ukraini pivmiliona bukhhalteriv. My ziasuvaly, shcho yikh khvyliuie. Aviable from: https://finance.liga.net/ekonomika/opinion/vukraine-polmilliona-buhgalterov-my-vyyasnili-chto-ih-volnuet. (In Ukrainian).

20. Rezultaty Zahalnonatsionalnoho onlain opytuvannia platnykiv podatkiv. Aviable from: http://sfs.gov.ua/data/files/246197.pdf. (In Ukrainian).

21. Sereda A. Opodatkuvannia medychnykh klinik, zakladiv okhorono zdorovia ta pryvatnykh likariv: PDV, prybutok, sudova praktyka. Aviable from: http://alltax.ua/pres-tsentr/publikatsii/380-opodatkuvannyamedichnikh-klinik-zakladiv-okhorono-zdorov-ya-ta-privatnikh-likarivpdv-pributok-sudova-praktika. (In Ukrainian).

22. Zadorozhnyi 0., Lapshyn Yu. Ckhodynkamy amerykanskoho dosvidu. Aviable from: http://www.visnuk.com.ua/ua/pubs/id/1561. (In Ukrainian).

\section{ORCID and contributionship:}

Vladislav I. Teremetskyi - 0000-0002-1469-052X A,D,F

Oleksandr M. Bandurka - 0000-0002-0240-5517 B,C,E

Emiliia S. Dmytrenko - 0000-0002-1469-052X $X^{A, D}$

Natalia I. Atamanchuk - 0000-0002-3893-084X $X^{B, E}$

Oleksandra O. Kochura - 0000-0003-0638-2911

\section{Conflicts of interest:}

Authors declare no conflict of interest.

\section{CORRESPONDING AUTHOR Vladislav I. Teremetskyi \\ Ternopil National Economic University, \\ 11 Lvivska str., Ternopil, 46009 Ukraine \\ tel: +380677625669 \\ e-mail:vladvokat333@ukr.net}

Received: 17.09 .2019

Accepted: 21.01 .2020

A - Work concept and design, B - Data collection and analysis, C - Responsibility for statistical analysis,

D-Writing the article, $\mathbf{E}$-Critical review, $\mathbf{F}$ - Final approval of the article 